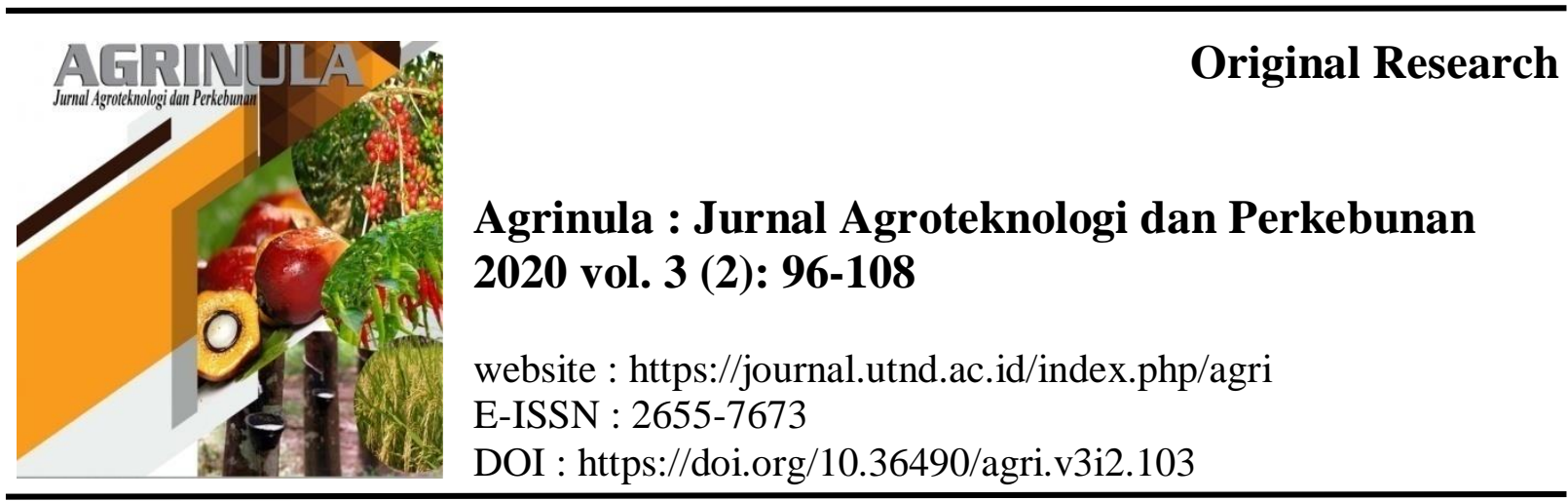

APLIKASI PUPUK ANORGANIK DAN WAKTU RENDAM BENIH DENGAN BAKTERI LEGUM PADA KACANG TANAH DI LAHAN PASANG SURUT

\title{
APPLICATION OF ANORGANIC FERTILIZERS AND SEED SOAKING TIME WITH LEGUME BACTERIA ON PEANUT IN TIDAL LOWLAND
}

Billy Andreas Putra ${ }^{1}$, Tengku Boumedine Hamid Zulkifli ${ }^{1 *}$, Yunida Berliana ${ }^{1}$ \& Octanina Sari Sijabat ${ }^{2}$

${ }^{1}$ Program Studi Agroteknologi, Fakultas Pertanian dan Peternakan, Universitas Tjut Nyak Dhien, Medan 20123, Sumatera Utara, Indonesia

${ }^{2}$ Program Studi Budidaya Perkebunan, Fakultas Pertanian dan Peternakan, Universitas Tjut Nyak Dhien, Medan 20123, Sumatera Utara, Indonesia

*Koresponding author: tengku_bobhz@yahoo.co.id

\begin{tabular}{|c|c|}
\hline Informasi Artikel & ABSTRAK \\
\hline $\begin{array}{l}\text { Disubmit: } \\
\text { 07 Oktober } 2020 \\
\text { Direvisi: } \\
22 \text { Oktober } 2020 \\
\text { Diterima: } \\
23 \text { Oktober } 2020 \\
\text { Dipublikasi : } \\
23 \text { Oktober } 2020\end{array}$ & $\begin{array}{l}\text { - Pendahuluan: Tujuan penelitian ini untuk mengetahui } \\
\text { dosis pupuk anorganik, waktu rendam inokulasi strain } \\
\text { bakteri legum yang sesuai terhadap pertumbuhan dan } \\
\text { produksi kacang tanah di lahan pasang surut. } \\
\text { - Metode Penelitian: Penelitian ini dilaksanakan di lahan } \\
\text { pasang surut di Desa Sei Ular, Kecamatan Secanggang, } \\
\text { Kabupaten Langkat Sumatera Utara pada September- } \\
\text { Desember } 2019 \text {. Rancangan penelitian yang digunakan } \\
\text { adalah Rancangan Acak Kelompok Faktorial. Faktor } \\
\text { pertama adalah dosis pupuk anorganik terdiri dari } \mathrm{P}_{0}= \\
\text { tanpa pupuk (kontrol), } \mathrm{P}_{1}=\text { urea } 50 \mathrm{~kg} / \mathrm{ha}+\mathrm{TSP} 180 \\
\mathrm{~kg} / \mathrm{ha}+\mathrm{KCl} 50 \mathrm{~kg} / \mathrm{ha}, \mathrm{P}_{2}=\text { urea } 75 \mathrm{~kg} / \mathrm{ha}+\mathrm{TSP} 205 \\
\mathrm{~kg} / \mathrm{ha}+\mathrm{KCl} 75 \mathrm{~kg} / \mathrm{ha}, \mathrm{P}_{3}=\text { urea } 100 \mathrm{~kg} / \mathrm{ha}+\mathrm{TSP} 230 \\
\mathrm{~kg} / \mathrm{ha}+\mathrm{KCl} 100 \mathrm{~kg} / \mathrm{ha} \text {. Faktor kedua adalah lamanya } \\
\text { waktu perendaman inokulasi strain bakteri } \\
\text { Bradyrhizobium japonicum terdiri dari } \mathrm{T}_{0}=\text { tanpa waktu } \\
\text { perendaman, } \mathrm{T}_{1}=\mathrm{waktu} \text { perendaman selama } 3 \text { menit, } \\
\mathrm{T}_{2}=\mathrm{waktu} \text { perendaman selama } 6 \text { menit, dan } \mathrm{T}_{3}= \\
\text { waktu perendaman selama } 9 \text { menit. Parameter }\end{array}$ \\
\hline
\end{tabular}

Agrinula : Jurnal Agroteknologi dan Perkebunan, 2020 vol. 3 (2): 96-108 


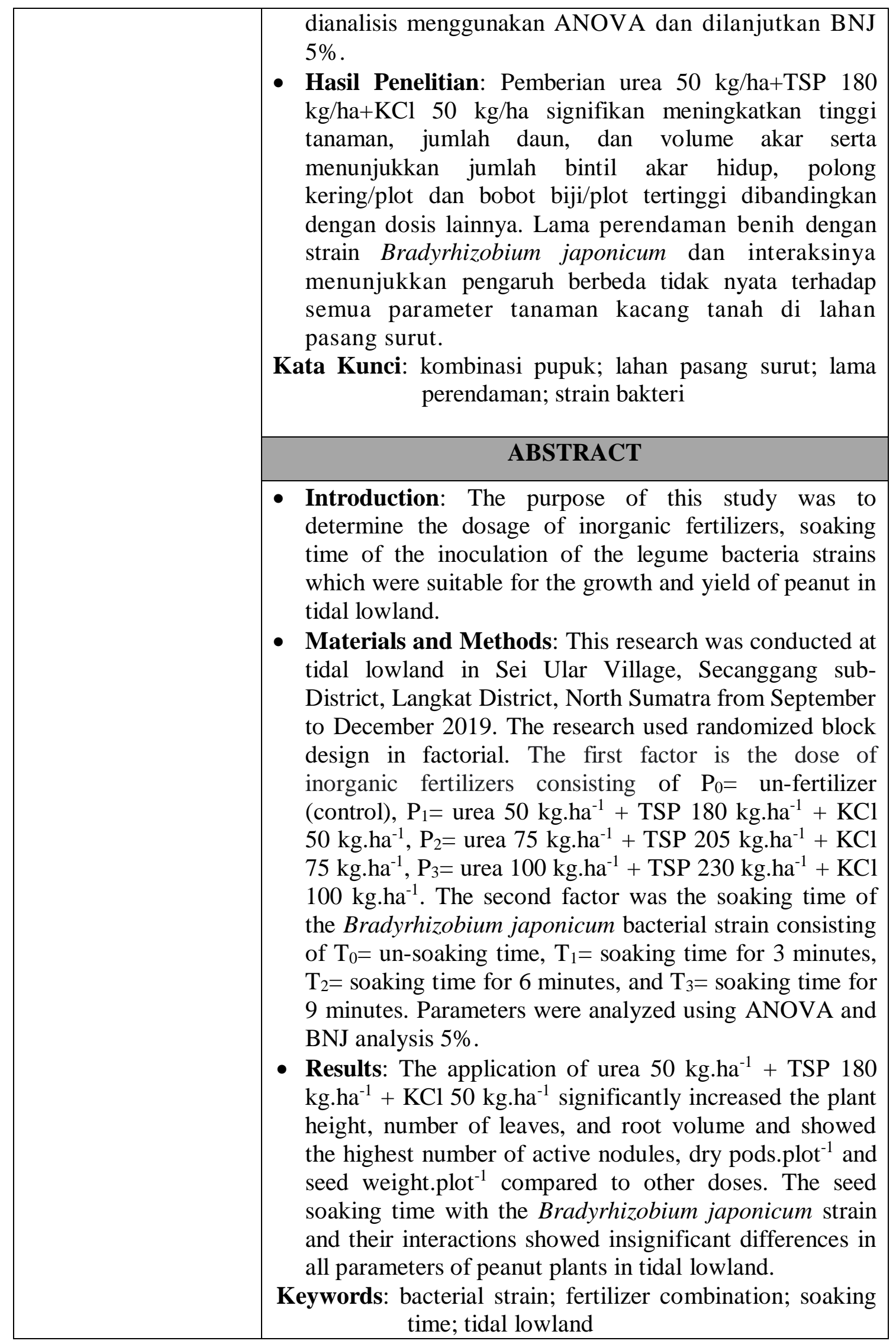




\section{PENDAHULUAN}

Indonesia menempati urutan ketiga terbesar di kawasan Asia menurut luas arealnya (650.000 ha) setelah India (9,0 juta ha) dan Cina (2,2 juta ha). Selain itu, Indonesia dikenal sebagai negara ketujuh terbesar penghasil kacang tanah di dunia setelah India, Cina, Nigeria, Senegal, Amerika Serikat,dan Brazil (Adisarwanto, 2007). Produksi kacang tanah dalam negeri selama tiga dekade terakhir menunjukkan pertumbuhan yang positif. Namun produksi tersebut belum bisa memenuhi permintaan yang semakin meningkat, sehingga jumlah impor kacang tanah meningkat tajam. Berdasarkan data FAO, Indonesia menjadi negara importir nomor dua dunia yang mengimpor kacang tanah dengan rata-rata 137,17 ribu ton pada tahun 2009-2013 (Badan Pusat Statistik, 2018).

Pengembangan pertanian lahan pasang surut merupakan langkah strategis dalam menjawab permasalahan peningkatan produksi pertanian yang makin kompleks. Namun, masalah fisiko kimia lahan yang dihadapi dalam pengembangan tanaman pangan di lahan pasang surut meliputi genangan air dan kondisi fisik lahan, kemasaman tanah, dan asam organik yang tinggi pada lahan gambut, zat beracun dan intrusi air bergaram, kesuburan alami yang rendah dan keragaman kondisi lahan yang tinggi (Suriadikarta \& Sutriadi, 2007). Khususnya di Provinsi Sumatera Utara luas lahan rawa atau lahan pasang surut sekitar 1.849.208 ha (BPS Sumatera Utara, 2018). Permasalahan pemanfaatan lahan rawa pasang surut untuk budidaya tanaman pangan menghadapi beberapa hambatan dan masalah, diantaranya kesuburan tanah yang rendah, reaksi tanah yang masam, adanya pirit, tingginya kadar $\mathrm{Al}, \mathrm{Fe}, \mathrm{Mn}$, dan asam organik, kahat $\mathrm{P}$, rendahnya kation basa seperti $\mathrm{Ca}, \mathrm{P}, \mathrm{K}, \mathrm{Mg}$, serta tertekannya aktivitas mikroba (Abdurachman \& Ananto, 2000).

Dengan demikian dibutuhkan pengembangan pertanian lahan pasang surut melalui penggunaan pupuk anorganik dan inokulasi strain bakteri. Menurut Arista et al., (2015), kombinasi dosis pupuk N, P dan $\mathrm{K}$ signifikan meningkatkan berat brangkasan kering tanaman kacang tanah. Margaretha et al., (2015) melaporkan bahwa pemberian urea $12,5 \mathrm{~kg} / \mathrm{ha}+\mathrm{SP}-3615 \mathrm{~kg} / \mathrm{ha}+\mathrm{KCl} 12,5 \mathrm{~kg} / \mathrm{ha}+$ Slurry cair $2 \mathrm{l} / \mathrm{ha}$ menunjukkan hasil tertinggi dalam meningkatkan tinggi tanaman, jumlah daun, bobot bintil akar, bobot berangkas,jumlah polong, serapan hara NPK, dan bobot biji kering kacang hijau. Marzuki (2007) menyatakan bahwa lahan yang baru pertama kali ditanami kacangkacangan termasuk kacang tanah, umumnya tidak menghasilkan polong sempurna tanpa diberi inokulasi bakteri akar.

Tujuan penelitian ini untuk mengetahui pengaruh pemberian pupuk anorganik serta inokulasi strain bakteri terhadap pertumbuhan dan produksi kacang tanah di lahan pasang surut.

\section{BAHAN DAN METODE}

\section{Tempat dan Waktu Penelitian}

Penelitian ini dilaksanakan di lahan pasang surut di Desa Sei Ular, Kecamatan Secanggang, Kabupaten Langkat, Sumatera Utara pada September-Desember 2019. 
Analisis tanah dilakukan di Laboratorium Fakultas Pertanian, Universitas Islam Sumatera Utara (UISU), Medan.

\section{Bahan dan Alat Penelitian}

Bahan yang digunakan pupuk urea, $\mathrm{TSP}, \mathrm{KCl}$, cairan yang dipakai untuk perendaman benih adalah strain Bradyrhizobium japonicum, pestisida, herbisida roundup.Alat yang digunakan adalah cangkul, gembor, label nama, alat tulis, plastik, ember, meteran, kalkulator, pompa air, genset listrik.

\section{Pembuatan Plot Penelitian}

Lahan areal penelitian dibersihkan dari gulma kemudian dibentuk plot penelitian berukuran $3 \mathrm{~m}$ x 1,5 $\mathrm{m}$. Setiap percobaan dalam satu ulangan dibatasi oleh parit drainase selebar 0,5 m, dan jarak antar blok percobaan selebar $1 \mathrm{~m}$.

\section{Perendaman Benih dengan Bakteri Legum}

Perendaman dengan Strain Bradyrhizobium japonicum dilakukan pada benih kacang tanah sesuai perlakuan. Benih kacang tanah direndam dengan air yang dicampur dengan Strain Bradyrhizobium japonicum pada ember plastik pada saat tanam, lalu ditanam langsung pada plot penelitian.

\section{Analisis Tanah}

Analisis tanah dilakukan sebelum penanaman (awal) dan akhir penelitian dengan mengambil sampel tanah sedalam $20 \mathrm{~cm}$ kemudian dikompositkan dan dilakukan analisis beberapa karakter kimia tanah (Tabel 1).

Tabel 1. Karakter kimia tanah awal dan akhir penelitian dari lahan pasang surut di Desa Sei Ular, Kecamatan Secanggang, Kabupaten Langkat.

\begin{tabular}{lcc}
\hline \multicolumn{1}{c}{ Karakter Kimia Tanah } & Analisis Awal & Analisis Akhir \\
\hline $\mathrm{N}$-total $(\%)$ & 0,08 & 0,13 \\
$\mathrm{P}_{2} \mathrm{O}_{5}(\mathrm{Bray}-\mathrm{II})$ & 11,31 & 14,31 \\
$\mathrm{~K}$-dd $(\mathrm{me} / 100 \mathrm{~g})$ & 0,18 & 0,18 \\
$\mathrm{DHL}(\mu \mathrm{s} / \mathrm{cm})$ & 3,01 & 3,61 \\
$\mathrm{Pyrit}-\mathrm{FeO}_{2}$ & 10,43 & 8,03 \\
\multicolumn{1}{c}{$-\mathrm{SO}_{4}$} & 39,31 & 32,11 \\
\hline
\end{tabular}

\section{Penanaman}

Benih yang digunakan diseleksi kemudian ditanam dengan cara menugal sedalam 2-3 cm sebanyak 2 benih/lubang dengan jarak tanam $30 \mathrm{~cm}$ x $20 \mathrm{~cm}$.

\section{Rancangan Penelitian}

Penelitian ini dilakukan menggunakan Rancangan Acak Kelompok (RAK) Faktorial dengan dua faktor yaitu faktor pertama (pupuk anorganik) terdiri atas $\mathrm{Po}=$ tanpa pupuk (kontrol), $\mathrm{P}_{1}=$ urea $50 \mathrm{~kg} / \mathrm{ha}+\mathrm{TSP} 180 \mathrm{~kg} / \mathrm{ha}+\mathrm{KCl} 50 \mathrm{~kg} / \mathrm{ha}, \mathrm{P}_{2}=$ urea $75 \mathrm{~kg} / \mathrm{ha}+\mathrm{TSP} 205 \mathrm{~kg} / \mathrm{ha}+\mathrm{KCl} 75 \mathrm{~kg} / \mathrm{ha}, \mathrm{P}_{3}=$ urea 100/ha+TSP $230 \mathrm{~kg} / \mathrm{ha}+\mathrm{KCl}$ $100 \mathrm{~kg} / \mathrm{ha}$. Faktor kedua lamanya waktu perendaman inokulasi strain bakteri Bradyrhizobium japonicum terdiri atas $\mathrm{T}_{0}=$ tanpa waktu perendaman, $\mathrm{T}_{1}=$ waktu perendamanselama 3 menit, $\mathrm{T}_{2}=$ waktu perendaman selama 6 menit, dan $\mathrm{T}_{3}=$ waktu perendaman selama 9 menit. 


\section{Pemeliharaan Tanaman}

Penyiraman dilakukan pada pagi dan sore hari, pada masa awal pertumbuhan dan tergantung keadaan cuaca setempat. Penjarangan tanaman dan penyulaman dilakukan setelah tanaman berumur satu minggu. Pembumbunan dilakukan pada 6 minggu setelah tanam, dilakukan dengan cara menarik tanah diantara barisan tanam ke arah barisan tanaman sampai kira-kira setinggi $10 \mathrm{~cm}$. Pengendalian gulma dilakukan secara manual dengan cara mencabut seluruh gulma yang terdapat di areal pertanaman. Penyiangan dilakukan satu kali dua minggu terutama sebelum tajuk tanaman saling menutupi.Pengendalian hama dan penyakit dilakukan secara rutin sekali dalam dua minggu dengan penyemprotan pestisida untuk menghindari adanya serangan hama dan penyakit.

\section{Pemanenan}

Pemanenan dilakukan dengan cara mencabut, dimana areal terlebih dahulu disiram untuk mempermudah pencabutan tanaman. Panen dilakukan ketika tanaman telah menunjukkan ciri-ciri panen sebagai berikut: sebagian daun telah menguning dan mulai berguguran, polong sudah mengeras dan batang menguning. Panen dilakukan pada waktu umur tanaman kacang tanah berumur 95 hari.

\section{Parameter dan Prosedur Analisis Data}

Paramter dalam penelitian ini meliputi tinggi tanaman $(\mathrm{cm})$, luas daun $\left(\mathrm{cm}^{2}\right)$, volume akar (cc), jumlah bintil akar hidup, bobot polong kering/tanaman ( $\mathrm{g}$ ), bobot polong kering/plot (g), bobot biji/plot (g), dan bobot 100 biji kering/tanaman $(\mathrm{g})$.

Tinggi tanaman diukur dari permukaan tanah sampai dengan ujung titik tumbuhan batang utama tanaman contoh. Pengukuran dilakukan mulai saat tanaman berumur 10, 20, 30, dan 40 hari setelah tanam (HST). Luas daun diukur dengan menggunakan leaf area meter di laboratorium. diukur pada saat tanaman berumur 10, 20, 30, dan $40 \mathrm{HST}$. Volume akar dihitung pada saat tanaman berumur 10, 20, 30, dan 40 HST. Dimana akar yang sudah dibersihkan dimasukkan dalam gelas ukur yang sudah dimasukkan air. Lalu dilihat jumlah kenaikan volume air ini adalah nilai dari volume akar. Pengamatan jumlah bintil akar hidup dilakukan dengan cara menghitung jumlah bintil akar hidup pada masing-masing tanaman contoh. Pengamatan bobot polong kering/tanaman dilakukan saat polong dikeringkan selama 3 hari dalam satu tanaman pada saat panen, yang diambil dari 5 tanaman contoh lalu ditimbang. Pengamatan bobot polong kering/plot dilakukan saat polong dikeringkan selama 3 hari dari setiap plot perlakuan kemudian ditimbang. Bobot biji/plot dilakukan saat biji dikeringkan selama 3 hari dari setiap plot perlakuan kemudian ditimbang.Bobot 100 biji kering/tanaman dilakukan saat biji dikeringkan selama 3 hari, lalu biji kering diambil secara acak sebanyak 100 biji dari setiap perlakuan kemudian ditimbang dan dhitung dengan menggunakan rumus:

$$
\text { Bobot } 100 \text { biji kering/tanaman }=\frac{\text { Bobot biji } / \text { tanaman }}{\text { Jumlah biji } / \operatorname{tanaman}} \times 100 \text { biji }
$$


Parameter dianalisis menggunakan ANOVA dan dilanjutkan Uji Beda Jujur (BNJ) taraf 5\%.

\section{HASIL DAN PEMBAHASAN \\ Tinggi Tanaman (cm)}

Hasil analisis sidik ragam menunjukkan bahwa perlakuan pemberian pupuk anorganik berpengaruh nyata terhadap tinggi tanaman sedangkan perlakuan waktu perendaman strain bakteri serta interaksi keduanya berpengaruh tidak nyata terhadap tinggi tanaman. Uji beda rataan tinggi tanaman dengan pemberian pupuk anorganik dan waktu perendaman strain bakteri pada umur 20 HST disajikan pada Tabel 2.

Tabel 2. Tinggi tanaman $(\mathrm{cm})$ kacang tanah pada interaksi perlakuan pemberian pupuk anorganik dengan waktu rendam pada umur 20 HST.

\begin{tabular}{cccccc}
\hline Perlakuan & $\mathrm{P}_{0}$ & $\mathrm{P}_{1}$ & $\mathrm{P}_{2}$ & $\mathrm{P}_{3}$ & Rataan \\
\hline $\mathrm{T}_{0}$ & 8,57 & 8,97 & 8,62 & 8,47 & 8,66 \\
$\mathrm{~T}_{1}$ & 8,40 & 9,14 & 8,73 & 8,59 & 8,72 \\
$\mathrm{~T}_{2}$ & 8,58 & 9,25 & 8,50 & 8,54 & 8,72 \\
$\mathrm{~T}_{3}$ & 8,59 & 9,00 & 8,63 & 8,77 & 8,75 \\
\hline Rataan & $8,54 \mathrm{a}$ & $9,09 \mathrm{~b}$ & $8,62 \mathrm{a}$ & $8,59 \mathrm{a}$ & $\mathrm{KK}=6,34 \%$ \\
\hline
\end{tabular}

Keterangan: angka-angka yang diikuti oleh huruf yang sama pada baris atau kolom yang sama menunjukkan tidak berbeda nyata pada taraf 5\% menggunakan BNJ.

Hasil uji beda rataan Tabel 2 terlihat bahwa pemberian pupuk anorganik berpengaruh nyata terhadap tinggi tanaman dimana $\mathrm{P}_{1}(9,09 \mathrm{~cm})$ berbeda nyata dengan $\mathrm{P}_{2}(8,62 \mathrm{~cm}), \mathrm{P}_{3}(8,59 \mathrm{~cm})$ dan $\mathrm{P}_{1}(8,54 \mathrm{~cm})$. Perlakuan waktu perendaman berpengaruh tidak nyata terhadap tinggi tanaman dengan perlakuan tertinggi $\mathrm{T}_{3}(8,75 \mathrm{~cm})$ diikuti dengan perlakuan $\mathrm{T}_{2}(8,72 \mathrm{~cm}), \mathrm{T}_{1}(8,72 \mathrm{~cm})$ dan $\mathrm{T}_{0}(8,66 \mathrm{~cm})$. Interaksi kedua perlakuan berpengaruh tidak nyata terhadap tinggi tanaman dengan perlakuan tertinggi $\mathrm{P}_{1} \mathrm{~T}_{2}(9,25 \mathrm{~cm})$.

\section{Luas Daun $\left(\mathrm{cm}^{2}\right)$}

Hasil analisis sidik ragam menunjukkan bahwa perlakuan pemberian pupuk anorganik berpengaruh nyata terhadap luas daun sedangkan perlakuan waktu perendaman strain bakteri serta interaksi keduanya berpengaruh tidak nyata terhadap luas daun. Uji beda rataan luas daun dengan pemberian pupuk anorganik dan waktu perendaman strain bakteri pada umur 20 HST disajikan pada Tabel 3.

Tabel 3. Luas daun $\left(\mathrm{cm}^{2}\right)$ tanaman kacang tanah pada interaksi perlakuan pemberian pupuk anorganik dan waktu perendaman pada umur $20 \mathrm{HST}$.

\begin{tabular}{cccccc}
\hline Perlakuan & $\mathrm{P}_{0}$ & $\mathrm{P}_{1}$ & $\mathrm{P}_{2}$ & $\mathrm{P}_{3}$ & Rataan \\
\hline $\mathrm{T}_{0}$ & 16,61 & 16,51 & 16,39 & 16,39 & 16,48 \\
$\mathrm{~T}_{1}$ & 16,69 & 16,47 & 16,63 & 16,21 & 16,50 \\
$\mathrm{~T}_{2}$ & 16,39 & 17,06 & 16,59 & 16,61 & 16,66 \\
$\mathrm{~T}_{3}$ & 16,69 & 16,88 & 16,26 & 16,18 & 16,50 \\
\hline Rataan & $16,59 \mathrm{a}$ & $16,73 \mathrm{~b}$ & $16,47 \mathrm{a}$ & $16,35 \mathrm{a}$ & $\mathrm{KK}=2,29 \%$ \\
\hline
\end{tabular}

Keterangan: angka-angka yang diikuti oleh huruf yang sama pada baris atau kolom yang sama menunjukkan tidak berbeda nyata pada taraf 5\% menggunakan BNJ. 
Hasil uji beda rataan Tabel 3 terlihat bahwa pemberian pupuk anorganik berpengaruh nyata terhadap luas daun dimana $\mathrm{P}_{1}\left(16,73 \mathrm{~cm}^{2}\right)$ berbeda nyata dengan $\mathrm{P}_{0}$ $\left(16,59 \mathrm{~cm}^{2}\right), \quad \mathrm{P}_{2}\left(16,47 \mathrm{~cm}^{2}\right)$ dan $\mathrm{P}_{3}\left(16,35 \mathrm{~cm}^{2}\right)$. Perlakuan waktu perendaman berpengaruh tidak nyata terhadap luas daun dengan perlakuan tertinggi $\mathrm{T}_{2}\left(16,66 \mathrm{~cm}^{2}\right)$ diikuti dengan perlakuan $\mathrm{T}_{3}(16,50 \mathrm{~cm} 2), \mathrm{T}_{1}\left(16,50 \mathrm{~cm}^{2}\right)$ dan $\mathrm{T}_{0}\left(16,48 \mathrm{~cm}^{2}\right)$. Interaksi kedua perlakuan berpengaruh tidak nyata terhadap luas daun dengan perlakuan tertinggi $\mathrm{P}_{1} \mathrm{~T}_{2}\left(17,06 \mathrm{~cm}^{2}\right)$.

\section{Volume Akar (cc)}

Hasil analisis sidik ragam menunjukkan bahwa perlakuan pemberian pupuk anorganik, perlakuan waktu perendaman strain bakteri serta interaksi keduanya berpengaruh tidak nyata terhadap volume akar pada umur 10, 20, 30, dan 40 HST (Tabel 4).

Tabel 4. Uji beda rataan volume akar dengan pemberian pupuk anorganik dan waktu perendaman strain bakteri pada umur 10, 20, 30 dan 40 HST.

\begin{tabular}{|c|c|c|c|c|}
\hline \multirow{2}{*}{ Perlakuan } & \multicolumn{4}{|c|}{ Volume akar pada umur (HST) } \\
\hline & 10 & 20 & 30 & 40 \\
\hline $\mathrm{P}_{0}$ & $0,17 \mathrm{a}$ & $0,30 \mathrm{a}$ & $0,74 \mathrm{a}$ & $1,24 \mathrm{a}$ \\
\hline $\mathrm{P}_{1}$ & $0,17 \mathrm{a}$ & $0,33 \mathrm{~b}$ & $0,76 \mathrm{a}$ & $1,24 \mathrm{a}$ \\
\hline $\mathrm{P}_{2}$ & $0,16 \mathrm{a}$ & $0,30 \mathrm{a}$ & $0,74 \mathrm{a}$ & $1,25 \mathrm{a}$ \\
\hline $\mathrm{P}_{3}$ & $0,18 \mathrm{~b}$ & $0,31 \mathrm{a}$ & $0,79 \mathrm{~b}$ & $1,26 \mathrm{~b}$ \\
\hline $\mathrm{T}_{0}$ & 0,17 & 0,31 & 0,74 & 1,24 \\
\hline $\mathrm{T}_{1}$ & 0,17 & 0,31 & 0,76 & 1,25 \\
\hline $\mathrm{T}_{2}$ & 0,17 & 0,32 & 0,77 & 1,25 \\
\hline $\mathrm{T}_{3}$ & 0,17 & 0,31 & 0,75 & 1,24 \\
\hline $\mathrm{P}_{0} \mathrm{~T}_{0}$ & 0,17 & 0,30 & 0,73 & 1,23 \\
\hline $\mathrm{P}_{0} \mathrm{~T}_{1}$ & 0,17 & 0,30 & 0,73 & 1,23 \\
\hline $\mathrm{P}_{0} \mathrm{~T}_{2}$ & 0,17 & 0,31 & 0,73 & 1,23 \\
\hline $\mathrm{P}_{0} \mathrm{~T}_{3}$ & 0,16 & 0,29 & 0,75 & 1,26 \\
\hline $\mathrm{P}_{1} \mathrm{~T}_{0}$ & 0,17 & 0,34 & 0,71 & 1,22 \\
\hline $\mathrm{P}_{1} \mathrm{~T}_{1}$ & 0,18 & 0,33 & 0,77 & 1,23 \\
\hline $\mathrm{P}_{1} \mathrm{~T}_{2}$ & 0,18 & 0,31 & 0,84 & 1,29 \\
\hline $\mathrm{P}_{1} \mathrm{~T}_{3}$ & 0,16 & 0,33 & 0,73 & 1,22 \\
\hline $\mathrm{P}_{2} \mathrm{~T}_{0}$ & 0,17 & 0,30 & 0,73 & 1,23 \\
\hline $\mathrm{P}_{2} \mathrm{~T}_{1}$ & 0,15 & 0,28 & 0,75 & 1,28 \\
\hline $\mathrm{P}_{2} \mathrm{~T}_{2}$ & 0,16 & 0,30 & 0,75 & 1,25 \\
\hline $\mathrm{P}_{2} \mathrm{~T}_{3}$ & 0,17 & 0,30 & 0,71 & 1,23 \\
\hline $\mathrm{P}_{3} \mathrm{~T}_{0}$ & 0,17 & 0,30 & 0,80 & 1,27 \\
\hline $\mathrm{P}_{3} \mathrm{~T}_{1}$ & 0,18 & 0,31 & 0,79 & 1,26 \\
\hline $\mathrm{P}_{3} \mathrm{~T}_{2}$ & 0,18 & 0,34 & 0,77 & 1,23 \\
\hline $\mathrm{P}_{3} \mathrm{~T}_{3}$ & 0,18 & 0,30 & 0,80 & 1,26 \\
\hline
\end{tabular}

Keterangan: angka-angka yang diikuti oleh huruf yang sama pada baris atau kolom yang sama menunjukkan tidak berbeda nyata pada taraf 5\% menggunakan BNJ. 
Hasil uji beda rataan Tabel 4 terlihat bahwa pemberian pupuk anorganik berpengaruh nyata terhadap volume akar pada umur 10, 20, 30 dan 40 HST. Pada umur 40 HST perlakuan tertinggi $\mathrm{P}_{3}(1,26 \mathrm{cc})$ berbeda nyata dengan $\mathrm{P}_{2}(1,25 \mathrm{cc}), \mathrm{P}_{1}(1,24 \mathrm{cc})$ dan $\mathrm{P}_{0}(1,24 \mathrm{cc})$. Perlakuan waktu perendaman berpengaruh tidak nyata terhadap volume akar pada umur 10, 20, 30 dan 40 HST. Pada umur 40 HST perlakuan tertinggi $\mathrm{T}_{1}(1,25 \mathrm{cc})$ diikuti $\mathrm{T}_{2}(1,25 \mathrm{cc}), \mathrm{T}_{1}(1,24 \mathrm{cc})$ dan $\mathrm{T}_{0}(1,24 \mathrm{cc})$. Interaksi kedua perlakuan berpengaruh tidak nyata terhadap volume akar pada umur 10, 20, 30, dan 40 HST. Pada umur $40 \mathrm{HST}$ perlakuan tertinggi $\mathrm{P}_{1} \mathrm{~T}_{2}(1,29 \mathrm{cc})$.

\section{Jumlah Bintil Akar Hidup}

Hasil analisis sidik ragam menunjukkan bahwa perlakuan pemberian pupuk anorganik, perlakuan waktu perendaman strain bakteri serta interaksi keduanya berpengaruh tidak nyata terhadap jumlah bintil akar hidup pada umur 20 HST (Tabel 5). Tabel 5. Jumlah bintil akar hidup tanaman kacang tanah pada interaksi perlakuan pemberian pupuk anorganik dan waktu perendaman pada umur 20 HST.

\begin{tabular}{cccccc}
\hline Perlakuan & $\mathrm{P}_{0}$ & $\mathrm{P}_{1}$ & $\mathrm{P}_{2}$ & $\mathrm{P}_{3}$ & Rataan \\
\hline $\mathrm{T}_{0}$ & 6,11 & 7,78 & 6,44 & 7,00 & 6,83 \\
$\mathrm{~T}_{1}$ & 4,56 & 6,78 & 6,56 & 6,11 & 6,00 \\
$\mathrm{~T}_{2}$ & 6,33 & 6,89 & 6,56 & 6,33 & 6,53 \\
$\mathrm{~T}_{3}$ & 6,00 & 7,34 & 6,33 & 7,22 & 6,72 \\
\hline Rataan & 5,75 & 7,20 & 6,47 & 6,67 &
\end{tabular}

Keterangan: angka-angka yang diikuti oleh huruf yang sama pada baris atau kolom yang sama menunjukkan tidak berbeda nyata pada taraf 5\% menggunakan BNJ.

Hasil uji beda rataan Tabel 5 terlihat bahwa pemberian pupuk anorganik berpengaruh tidak nyata terhadap jumlah bintil akar hidup pada perlakuan tertinggi $\mathrm{P}_{1}$ $(7,20)$, diikuti $\mathrm{P}_{3}(6,67), \mathrm{P}_{2}(6,47), \mathrm{P}_{0}(5,75)$. Perlakuan waktu perendaman berpengaruh tidak nyata terhadap jumlah bintil akar hidup pada perlakuan tertinggi $\mathrm{T}_{0}(6,83)$ diikuti perlakuan $\mathrm{T}_{3}(6,72), \mathrm{T}_{2}(6,53)$ dan $\mathrm{T}_{1}(6,00)$. Interaksi kedua perlakuan berpengaruh tidak nyata terhadap jumlah bintil akar hidup pada perlakuan tertinggi $\mathrm{P}_{1} \mathrm{~T}_{0}(7,78)$.

\section{Bobot Polong Kering/Tanaman (g)}

Hasil analisis sidik ragam menunjukkan bahwa perlakuan pemberian pupuk anorganik, perlakuan waktu perendaman strain bakteri serta interaksi keduanya berpengaruh tidak nyata terhadap bobot polong kering/tanaman umur 40 HST (Tabel 6). Tabel 6. Bobot polong kering/tanaman kacang tanah pada interaksi perlakuan pemberian pupuk anorganik dan waktu perendaman $40 \mathrm{HST}$.

\begin{tabular}{cccccc}
\hline Perlakuan & $\mathrm{P}_{0}$ & $\mathrm{P}_{1}$ & $\mathrm{P}_{2}$ & $\mathrm{P}_{3}$ & Rataan \\
\hline $\mathrm{T}_{0}$ & 13,71 & 12,76 & 13,03 & 14,03 & 13,38 \\
$\mathrm{~T}_{1}$ & 14,89 & 12,16 & 14,79 & 12,50 & 13,59 \\
$\mathrm{~T}_{2}$ & 11,38 & 12,90 & 13,50 & 12,73 & 12,63 \\
$\mathrm{~T}_{3}$ & 12,40 & 13,51 & 14,19 & 11,05 & 12,79 \\
\hline Rataan & 13,09 & 12,83 & 13,88 & 12,58 & \\
\hline
\end{tabular}

Keterangan: angka-angka yang diikuti oleh huruf yang sama pada baris atau kolom yang sama menunjukkan tidak berbeda nyata pada taraf 5\% menggunakan BNJ. 
Hasil uji beda rataan Tabel 6 terlihat bahwa pemberian pupuk anorganik berpengaruh tidak nyata terhadap bobot polong kering/tanaman dengan perlakuan tertinggi $\mathrm{P}_{2}(13,88 \mathrm{~g})$, diikuti $\mathrm{P}_{0}(13,09 \mathrm{~g}), \mathrm{P}_{1}(13,09 \mathrm{~g})$ dan $\mathrm{P}_{3}(12,58 \mathrm{~g})$. Perlakuan waktu perendaman berpengaruh tidak nyata terhadap bobot polong kering/tanaman dengan perlakuan tertinggi $\mathrm{T}_{1}(13,59 \mathrm{~g})$ diikuti dengan perlakuan $\mathrm{T}_{0}(13,38 \mathrm{~g}), \mathrm{T}_{3}(12,79$ g) dan $\mathrm{T}_{2}(12,63 \mathrm{~g})$. Interaksi kedua perlakuan berpengaruh tidak nyata terhadap bobot polong kering/tanaman dengan perlakuan tertinggi $\mathrm{P}_{0} \mathrm{~T}_{1}(14,89 \mathrm{~g})$.

\section{Bobot Polong Kering/Plot (g)}

Hasil analisis sidik ragam menunjukkan bahwa perlakuan pemberian pupuk anorganik, perlakuan waktu perendaman strain bakteri serta interaksinya berpengaruh tidak nyata terhadap bobot polong kering/plot (g) pada umur 40 HST (Tabel 7).

Tabel 7. Bobot polong kering/plot tanaman kacang tanah pada interaksi perlakuan pemberian pupuk anorganik dan waktu perendaman.

\begin{tabular}{cccccc}
\hline Perlakuan & $\mathrm{P}_{0}$ & $\mathrm{P}_{1}$ & $\mathrm{P}_{2}$ & $\mathrm{P}_{3}$ & Rataan \\
\hline $\mathrm{T}_{0}$ & 59,49 & 68,63 & 70,71 & 69,44 & 67,07 \\
$\mathrm{~T}_{1}$ & 62,26 & 72,53 & 60,34 & 70,93 & 66,51 \\
$\mathrm{~T}_{2}$ & 65,42 & 68,33 & 68,73 & 66,61 & 67,27 \\
$\mathrm{~T}_{3}$ & 65,19 & 70,77 & 66,95 & 68,01 & 67,73 \\
\hline Rataan & 63,09 & 70,07 & 66,68 & 68,75 & \\
\hline
\end{tabular}

Keterangan: angka-angka yang diikuti oleh huruf yang sama pada baris atau kolom yang sama menunjukkan tidak berbeda nyata pada taraf $5 \%$ menggunakan Uji BNJ.

Hasil uji beda rataan Tabel 7 terlihat bahwa pemberian pupuk anorganik berpengaruh tidak nyata terhadap bobot polong kering/plot dengan perlakuan tertinggi $\mathrm{P}_{1}(70,07 \mathrm{~g})$, diikuti $\mathrm{P}_{3}(68,75 \mathrm{~g}), \mathrm{P}_{2}(66,68 \mathrm{~g})$ dan $\mathrm{P}_{0}(63,09 \mathrm{~g})$. Perlakuan waktu perendaman berpengaruh tidak nyata terhadap bobot polong kering/plot dengan perlakuan tertinggi $\mathrm{T}_{3}(67,73 \mathrm{~g})$ diikuti dengan perlakuan $\mathrm{T}_{2}(67,72 \mathrm{~g}), \mathrm{T}_{0}(67,07 \mathrm{~g})$ dan $\mathrm{T}_{1}(66,51 \mathrm{~g})$. Interaksi kedua perlakuan berpengaruh tidak nyata terhadap bobot polong kering/plot dengan perlakuan tertinggi $\mathrm{P}_{1} \mathrm{~T}_{1}(72,53 \mathrm{~g})$.

\section{Bobot Biji/Plot (g)}

Hasil analisis sidik ragam menunjukkan bahwa perlakuan pemberian pupuk anorganik, perlakuan waktu perendaman strain bakteri serta interaksi keduanya berpengaruh tidak nyata terhadap bobot biji/plot pada umur 40 HST (Tabel 8).

Tabel 8. Bobot biji/plot kacang tanah pada interaksi perlakuan pemberian pupuk anorganik dengan waktu perendaman.

\begin{tabular}{cccccc}
\hline Perlakuan & $\mathrm{P}_{0}$ & $\mathrm{P}_{1}$ & $\mathrm{P}_{2}$ & $\mathrm{P}_{3}$ & Rataan \\
\hline $\mathrm{T}_{0}$ & 33,14 & 35,58 & 30,45 & 30,20 & 32,34 \\
$\mathrm{~T}_{1}$ & 29,46 & 33,26 & 29,56 & 32,56 & 31,21 \\
$\mathrm{~T}_{2}$ & 32,40 & 38,10 & 33,77 & 35,03 & 34,82 \\
$\mathrm{~T}_{3}$ & 30,43 & 33,76 & 31,94 & 35,33 & 32,86 \\
\hline Rataan & 31,36 & 35,17 & 31,43 & 33,28 & \\
\hline
\end{tabular}

Keterangan: angka-angka yang diikuti oleh huruf yang sama pada baris atau kolom yang sama menunjukkan tidak berbeda nyata pada taraf 5\% menggunakan BNJ. 
Hasil uji beda rataan Tabel 8 terlihat bahwa pemberian pupuk anorganik berpengaruh tidak nyata terhadap bobot biji/plot dengan perlakuan tertinggi $\mathrm{P}_{1}(35,17$ g), diikuti $\mathrm{P}_{3}(33,28 \mathrm{~g}), \mathrm{P}_{2}(31,43 \mathrm{~g})$ dan $\mathrm{P}_{0}(31,36 \mathrm{~g})$. Perlakuan waktu perendaman berpengaruh tidak nyata terhadap bobot biji/plot dengan perlakuan tertinggi $\mathrm{T}_{2}(34,82 \mathrm{~g})$ diikuti dengan perlakuan $\mathrm{T}_{3}(32,86 \mathrm{~g}), \mathrm{T}_{0}(32,34 \mathrm{~g})$ dan $\mathrm{T}_{1}(31,21 \mathrm{~g})$. Interaksi kedua perlakuan berpengaruh tidak nyata terhadap bobot biji/plot dengan perlakuan tertinggi $\mathrm{P}_{1} \mathrm{~T}_{2}(38,10 \mathrm{~g})$.

\section{Bobot 100 Biji Kering (g)}

Hasil analisis sidik ragam menunjukkan bahwa perlakuan pemberian pupuk anorganik, perlakuan waktu perendaman strain bakteri serta interaksi keduanya berpengaruh tidak nyata terhadap bobot 100 biji kering pada umur 40 HST (Tabel 9).

Tabel 9. Bobot 100 biji kering kacang tanah pada interaksi perlakuan pemberian pupuk anorganik dengan waktu perendaman.

\begin{tabular}{cccccc}
\hline Perlakuan & $\mathrm{P}_{0}$ & $\mathrm{P}_{1}$ & $\mathrm{P}_{2}$ & $\mathrm{P}_{3}$ & Rataan \\
\hline $\mathrm{T}_{0}$ & 35,63 & 32,25 & 30,45 & 30,20 & 32,13 \\
$\mathrm{~T}_{1}$ & 35,09 & 31,34 & 29,56 & 32,56 & 32,14 \\
$\mathrm{~T}_{2}$ & 32,40 & 29,08 & 33,43 & 35,03 & 32,48 \\
$\mathrm{~T}_{3}$ & 32,49 & 33,76 & 31,94 & 35,33 & 33,38 \\
\hline Rataan & 33,90 & 31,60 & 31,34 & 33,28 &
\end{tabular}

Keterangan: angka-angka yang diikuti oleh huruf yang sama pada baris atau kolom yang sama menunjukkan tidak berbeda nyata pada taraf 5\% menggunakan Uji BNJ.

Hasil uji beda rataan Tabel 9 terlihat bahwa pemberian pupuk anorganik berpengaruh tidak nyata terhadap bobot 100 biji kering dengan perlakuan tertinggi $\mathrm{P}_{0}$ $(33,90 \mathrm{~g})$, diikuti $\mathrm{P}_{3}(33,28 \mathrm{~g}), \mathrm{P}_{1}(31,60 \mathrm{~g})$ dan $\mathrm{P}_{2}(31,34 \mathrm{~g})$. Perlakuan waktu perendaman berpengaruh tidak nyata terhadap bobot 100 biji kering dengan perlakuan tertinggi $\mathrm{T}_{2}(34,82 \mathrm{~g})$ diikuti dengan perlakuan $\mathrm{T}_{3}(32,86 \mathrm{~g}), \mathrm{T}_{0}(32,34 \mathrm{~g})$ dan $\mathrm{T}_{1}(31,21$ g). Interaksi kedua perlakuan berpengaruh tidak nyata terhadap bobot 100 biji kering dengan perlakuan tertinggi $\mathrm{P}_{0} \mathrm{~T}_{0}(35,63 \mathrm{~g})$.

\section{Pembahasan}

\section{Pengaruh Pupuk Anorganik terhadap Pertumbuhan dan Produksi Kacang Tanah di Lahan Pasang Surut}

Hasil penelitian menunjukkan bahwa pemberian pupuk anorganik menunjukkan pengaruh berbeda nyata terhadap tinggi tanaman $(\mathrm{cm})$, luas daun $\left(\mathrm{cm}^{2}\right)$, dan volume akar (cc), namun berpengaruh tidak nyata terhadap jumlah bintil akar hidup, bobot polong kering/tanaman (g), bobot polong kering/plot (g), bobot biji/plot (g), dan bobot 100 biji kering/tanaman (g) kacang tanah di lahan pasang surut. Perlakuan $\mathrm{P}_{1}$ (urea $50 \mathrm{~kg} / \mathrm{ha}+\mathrm{TSP} 180 \mathrm{~kg} / \mathrm{ha}+\mathrm{KCl} 50 \mathrm{~kg} / \mathrm{ha}$ ) menunjukkan tinggi tanaman, luas daun, volume akar, jumlah bintil akar hidup, bobot polong kering/plot, dan bobot biji/plot tanaman kacang tanah tertinggi dibandingkan dosis lainnya. Perlakuan $\mathrm{P}_{2}$ (urea $75 \mathrm{~kg} / \mathrm{ha}+\mathrm{TSP} 205 \mathrm{~kg} / \mathrm{ha}+\mathrm{KCl} 75 \mathrm{~kg} / \mathrm{ha}$ ) dan tanpa pemupukan menunjukkan 
bobot polong kering/tanaman dan bobot 100 biji kering/tanaman kacang tanah tertinggi dibandingkan dosis lainnya.

Peningkatan pertumbuhan tanaman akibat pemberian pupuk NPK disebabkan karena unsur tersebut merupakan unsur hara makro yang dibutuhkan tanaman dalam jumlah besar untuk petumbuhan vegetatif dan generatif. Pupuk NPK tidak hanya meningkatkan pertumbuhan vegetatif tanaman melainkan juga meningkatkan produksi tanaman. Hal ini diduga bahwa unsur hara makro meningkatkan kandungan hormon dan senyawa kimia lainnya yang membantu dalam menjaga daya tahan tubuh. Hal ini dibuktikan oleh Novizan, (2005) dalam penelitian membuktikan bahwa pemupukan NPK dapat meningkatkan kandungan fitokimia. Lingga dan Marsono, (2007) menyatakan bahwa tanaman yang mendapat tambahan unsur $\mathrm{P}$ akan tumbuh lebih tinggi dari pada tanaman yang tidak diberi pupuk sehingga membantu dalam penambahan jumlah cabang yang banyak. Pembentukan jumlah cabang sejalan dengan pembentukan jumlah ginofor, dengan banyaknya jumlah ginofor maka akan semangkin banyak jumlah polong berisi.

Pengaruh Lama Perendaman Benih dengan Strain Bradyrhizobium japonicum terhadap Pertumbuhan dan Produksi Kacang Tanah di Lahan Pasang Surut

Hasil penelitian menunjukkan bahwa lama perendaman benih dengan strain Bradyrhizobium japonicum menunjukkan pengaruh tidak nyata terhadap tinggi tanaman $(\mathrm{cm})$, luas daun $\left(\mathrm{cm}^{2}\right)$, volume akar (cc), jumlah bintil akar hidup, bobot polong kering/tanaman $(\mathrm{g})$, bobot polong kering/plot $(\mathrm{g})$, bobot biji/plot $(\mathrm{g})$, dan bobot 100 biji kering/tanaman (g) kacang tanah di lahan pasang surut. Lama perendaman 6 menit $\left(\mathrm{T}_{2}\right)$ menunjukkan luas daun, volume akar, dan bobot biji/plot tanaman kacang tanah tertinggi dibandingkan lama perendaman lainnya. Lama perendaman 9 menit $\left(\mathrm{T}_{3}\right)$ menunjukkan tinggi tanaman, bobot polong kering/plot, dan bobot 100 biji kering/tanaman kacang tanah tertinggi dibandingkan lama perendaman lainnya. Perlakuan tanpa direndam juga menunjukkan jumlah bintil akar hidup, dan bobot polong kering/tanaman kacang tanah tertinggi dibandingkan lama perendaman lainnya. Dari hasil statistik dapat dilihat bahwa perlakuan $\mathrm{T}_{3}$ (lama perendaman 9 menit) meningkatkan bobot polong. Hal ini sesuai dengan Triadiati, (2013) inokulasi rhizobium efektif mempengaruhi pembentukan polong.

\section{Pengaruh Interaksi Pupuk Anorganik dan Lama Perendaman Benih dengan Strain Bradyrhizobium japonicum terhadap Pertumbuhan dan Produksi Kacang Tanah di Lahan Pasang Surut}

Hasil penelitian menunjukkan bahwa pemberian kombinasi pupuk anorganik dengan lama perendaman benih dengan strain Bradyrhizobium japonicum menunjukkan pengaruh tidak nyata terhadap tinggi tanaman $(\mathrm{cm})$, luas daun $\left(\mathrm{cm}^{2}\right)$, volume akar (cc), jumlah bintil akar hidup, bobot polong kering/tanaman (g), bobot polong kering/plot (g), bobot biji/plot (g), dan bobot 100 biji kering/tanaman (g) kacang 
tanah di lahan pasang surut. Hal ini dikarenakan kurang efektifnya strain Bradyrhizobium japonicum untuk bersimbiosis dengan pupuk anorganik. Rhizobium yang tidak efektif dapat membentuk bintil (infektif) namun tidak mampu menambat $\mathrm{N}$. Dengan demikian tanaman kacang-kacangan yang ditanam pada tanah yang mengandung rhizobium alam akan mengalami pembintilan oleh beberapa strain rhizobium yang tidak efektif maupun yang efektif. Menurut Bergersen et al., (1998) pola efektivitas populasi rhizobium alam dalam tanah mengikuti sebaran normal dengan rata-rata efektivitas hanya sekitar 50\% dari efektivitas strain rhizobium inokulum yang terseleksi.

\section{KESIMPULAN}

Pemberian pupuk $\mathrm{P}_{1}$ (urea $50 \mathrm{~kg} / \mathrm{ha}+\mathrm{TSP} 180 \mathrm{~kg} / \mathrm{ha}+\mathrm{KCl} 50 \mathrm{~kg} / \mathrm{ha}$ ) signifikan meningkatkan tinggi tanaman, jumlah daun, dan volume akar serta menunjukkan jumlah bintil akar hidup, polong kering/plot dan bobot biji/plot tertinggi dibandingkan dengan dosis lainnya. Lama perendaman benih dengan strain Bradyrhizobium japonicum dan interaksinya menunjukkan pengaruh berbeda tidak nyata terhadapsemua parameter tanaman kacang tanah di lahan pasang surut.

\section{DAFTAR PUSTAKA}

Abdurachman, A. E., \& Ananto, E. E. (2000). Konsep pengembangan pertanian berkelanjutan di lahan rawa untuk mendukung ketahanan pangan dan pengembangan agribisnis. Seminar Nasional Penelitian dan Pengembangan Pertanian di Lahan Rawa. Bogor, 25-27 Juli 2000. 23 hlm.

Adisarwanto. (2007). Meningkatkan produksi kacang tanah di lahan sawah dan lahan kering. Penebar Swadaya, Jakarta.

Arista, D., Suryono., \& Sudadi. (2015). Efek dari kombinasi pupuk N, P dan K terhadap pertumbuhan dan hasil kacang tanah pada lahan kering alfisol. Agrosains: Jurnal Penelitian Agronomi, 17(2), 49-52. https://doi.org/10.20961/agsjpa.v17i2.18672.

Badan Pusat Statistik Sumatera Utara. (2018). Provinsi Sumatera Utara dalam angka 2018. Medan, Sumatera Utara, Indonesia.

Badan Pusat Statistik. (2018). Statistik Indonesia dalam infografis 2018. Jakarta, Indonesia.

Bergersen, F. J., Brockwell, J., Gault, R. R., Morthorpe, L., Peoples, M. B., \& Turner, G. L. (1989). Effects of available soil $\mathrm{N}$ and rates of inoculation on nitrogen fixation by irrigated soybeans and evaluation of $\delta 15 \mathrm{~N}$ methods for measurement. Australian Journal of Agricultural Research, 40(4), 763-780. https://doi.org/10.1071/AR9890763.

Lingga, P., \& Marsono. (2007). Petunjuk Penggunaan Pupuk. Penebar Swadaya, Jakarta Margaretha, C., Yafizham., Hidayat, K. F., \& Karyanto, A. (2015). Pengaruh kombinasi dosis pupuk anorganik dan pupuk slurry cair terhadap pertumbuhan dan produksi tanaman kacang hijau (Phaseolus radiatus L). Jurnal Agrotek Tropika, 3(1), 18-23. http://dx.doi.org/10.23960/jat.v3i1.1887.

Marzuki, R. (2007). Bertanam kacang tanah. Penebar Swadaya, Jakarta.

Mulyadi, A. (2012). Pengaruh pemberian legin, pupuk NPK (15: 15: 15) dan urea pada tanah gambut terhadap kandungan $\mathrm{N}, \mathrm{P}$ total pucuk dan bintil akar kedelai (Glycine max (L.) Merr.). Jurnal Kaunia, 8(1), 21-29. 
Novizan. (2005). Petunjuk pemupukan yang efektif. Agro Media Pustaka, Jakarta

Suriadikarta, D. A., \& Sutriadi, M. T. (2007). Jenis-jenis lahan berpotensi untuk pengembangan pertanian di lahan rawa. Jurnal Litbang Pertanian, 26(3), 115122.

Triadiati, Mubarik, N. R., \& Ramasita, Y. (2013). Respon Pertumbunan Tanaman Kedelai terhadap Bradyrhizobium japonicum Toleran Masam dan Pemberian Pupuk di Tanah Masam. Jurnal Agrononi Indonesia, 41(1), 24-31. https://doi.org/10.24831/jai.v41i1.7072. 